\title{
Od uredništva - Erratum
}

\author{
EKG artefakati u urgentnoj medicini \\ ECG artefacts in emergency medicine \\ Uzelac M. Bojana \\ Gradski zavod za Hitnu medicinsku pomoć Beograd
}

$\mathrm{U} A B C$ časopisu urgentne medicine

201;(3):41-48, http://urgentnamedicina.sld.org.rs/sr/casopis/

Uredništvo je učinilo previd u radu koji je od strane autora poslat kao editorijal. Omaškom je radu dodeljena klasifikacija originalni članak $i$ rad je objavljen kao Originalni rad.

Ispravna klasifikacija rada je Editorijal. Za učinjeni propust autor rada ne snosi nikakvu odgovornost.

Propust je primetilo uredništvo $\mathrm{ABC}$ časopis urgentne medicine.

Uredništvo se izvinjava zbog povrede Publicističkih Standarda

Uredništvo $\mathrm{ABC}$ časopis urgentne medicine 